\title{
Tubulocystic Renal Cell Carcinoma Is Not an Indolent Tumor: A Case Report of Recurrences in the Retroperitoneum and Contralateral Kidney
}

\author{
Tae-Soo Choi ${ }^{1}$, Dong-Gi Lee ${ }^{1}$, Kyu-Yeoun Won ${ }^{2}$ and Gyeong-Eun Min ${ }^{1, *(D)}$ \\ 1 Department of Urology, Kyung Hee University College of Medicine, Seoul 05278, Korea; \\ taesoochoi85@hanmail.net (T.-S.C.); urology@khu.ac.kr (D.-G.L.) \\ 2 Department of Pathology, Kyung Hee University College of Medicine, Seoul 05278, Korea; \\ wonki96@khu.ac.kr \\ * Correspondence: danielmin@khu.ac.kr; Tel.: +82-2-440-7735; Fax: +82-2-440-7744
}

check for

updates

Citation: Choi, T.-S.; Lee, D.-G.; Won, K.-Y.; Min, G.-E. Tubulocystic Renal Cell Carcinoma Is Not an Indolent Tumor: A Case Report of Recurrences in the Retroperitoneum and Contralateral Kidney. Medicina 2021, 57, 851. https://doi.org/10.3390/ medicina57080851

Academic Editor:

Charat Thongprayoon

Received: 23 July 2021

Accepted: 19 August 2021

Published: 21 August 2021

Publisher's Note: MDPI stays neutral with regard to jurisdictional claims in published maps and institutional affiliations.

Copyright: (c) 2021 by the authors. Licensee MDPI, Basel, Switzerland. This article is an open access article distributed under the terms and conditions of the Creative Commons Attribution (CC BY) license (https:/ / creativecommons.org/licenses/by/ $4.0 /)$.

\begin{abstract}
Tubulocystic renal cell carcinoma (RCC) is a rare subtype of RCC that was recently included in the 2016 World Health Organization classification of tumors of the kidney. Most of these tumors exhibit indolent behavior with low metastatic potential. However, here we report a case of recurrent tubulocystic RCC with aggressive features in the retroperitoneum and contralateral kidney treated with targeted agents and radiofrequency ablation.
\end{abstract}

Keywords: carcinoma; renal cell; recurrence; neoplasm metastasis

\section{Introduction}

Tubulocystic renal cell carcinoma (RCC) is a subtype of RCC only recently included in the 2016 World Health Organization (WHO) classification of tumors of the kidney [1]. Most cases have low metastatic potential. Some tubulocystic RCC cases are misdiagnosed as renal cysts [2]. To date, the treatment of metastatic tubulocystic RCC has not been established. Herein, we report a case of recurrent tubulocystic RCC with aggressive features in the retroperitoneum and contralateral kidney treated with targeted agents and radiofrequency ablation (RFA).

\section{Case Report}

A 60-year-old man was referred to our department for a huge left renal cyst identified on computed tomography (CT), which revealed an approximately $14-\mathrm{cm}$-sized renal cyst with thin septa at the upper pole of the left kidney was observed (Figure 1). The preoperative CT findings were consistent with Bosniak classification II renal cyst. Subsequently, we performed laparoscopic renal cyst marsupialization. On pathologic examination, the tumor comprised a mixture of variably sized cysts and tubules, which were lined by a single layer of flattened, cuboidal or columnar cells. Hobnailing was observed. The subepithelial area demonstrated fibrous stroma and poorly differentiated tumor cells (Figures 2 and 3a). The pathological diagnosis was tubulocystic RCC. As the surgical margin status could not be evaluated, a radical nephrectomy was chosen. Two weeks after renal cyst marsupialization, the patient underwent radical nephrectomy. Pathologic examination revealed tumor cells in the residual kidney. Poorly differentiated foci of $1.5 \times 1.5 \mathrm{~cm}$ with pleomorphic nuclei and prominent nucleoli were observed (Figure 3b). The tumor cells were positive for cytokeratin, vimentin, and AMACR (Figure 3c); and negative for cytokeratin 7, and CD10. After 18 months, multiple small hypodense lesions in the left subphrenic space and along the lateral portion of the left retroperitoneal space were noted on an abdominal CT scan. The lesion density was $<10 \mathrm{HU}$, and the masses were cystic (Figure 4 ). The patient received a weekly dose of $25 \mathrm{mg}$ temsirolimus intravenously. After eight cycles of temsirolimus, the appearance of multiple retroperitoneal nodules was reduced on the abdominal CT. Weekly 
temsirolimus treatment was continued. After an additional eight cycles of temsirolimus, recurrent RCC was detected in the contralateral kidney (Figure 5). RFA of the recurrent RCC in the right kidney was performed after confirming the pathology through a percutaneous renal mass biopsy. Treatment of the retroperitoneal nodules was continued with $50 \mathrm{mg}$ of sunitinib. At the 9-month follow-up, the lesions were stable disease according to the RECIST criteria. The patient continually took sunitinib $50 \mathrm{mg}$ without major side effects other than mild fatigue and subclinical hypothyroidism, and his renal function was maintained at CKD stage 3a.

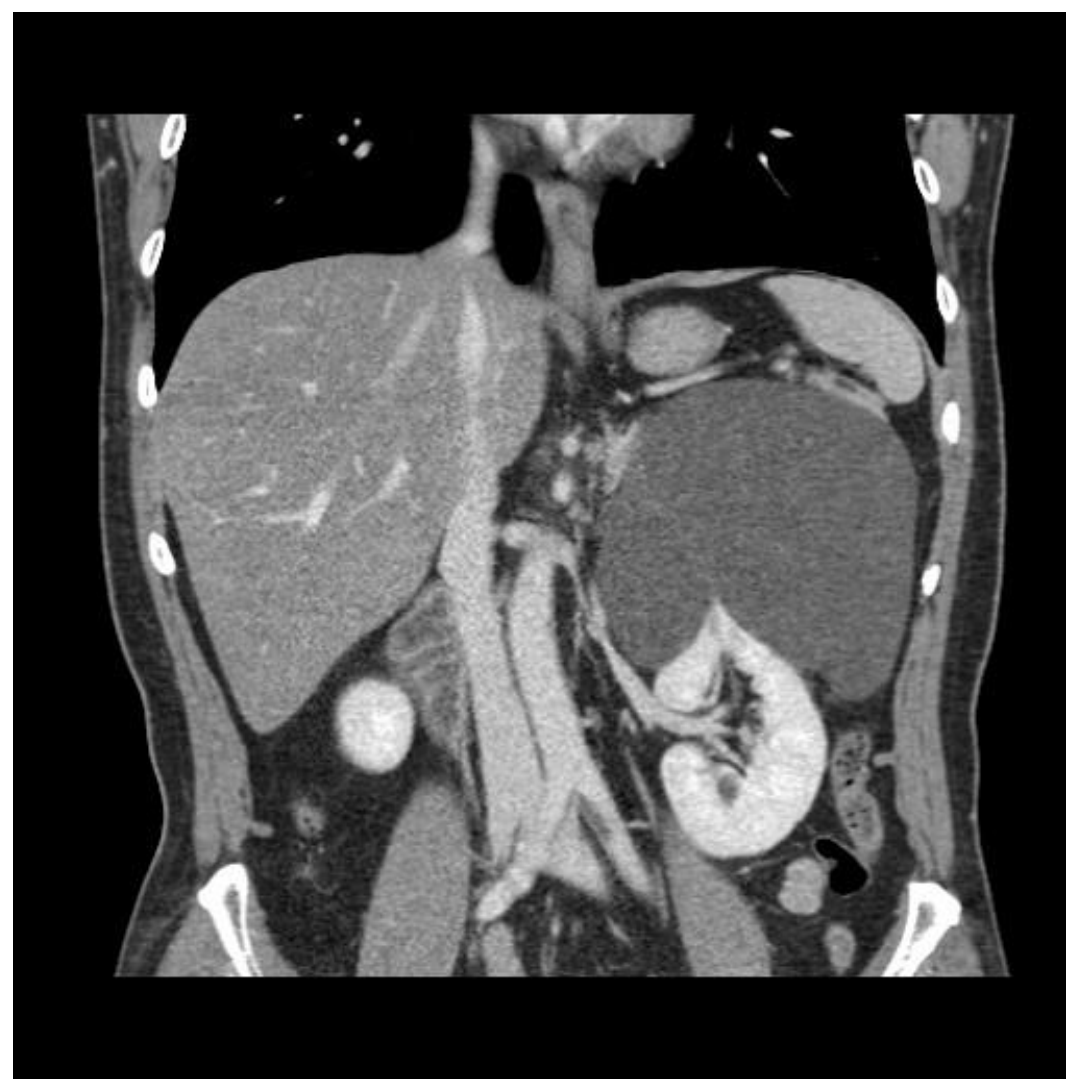

Figure 1. Preoperative CT scan revealed a $14 \mathrm{~cm}$-sized renal cyst with thin septa at the upper pole of left kidney.

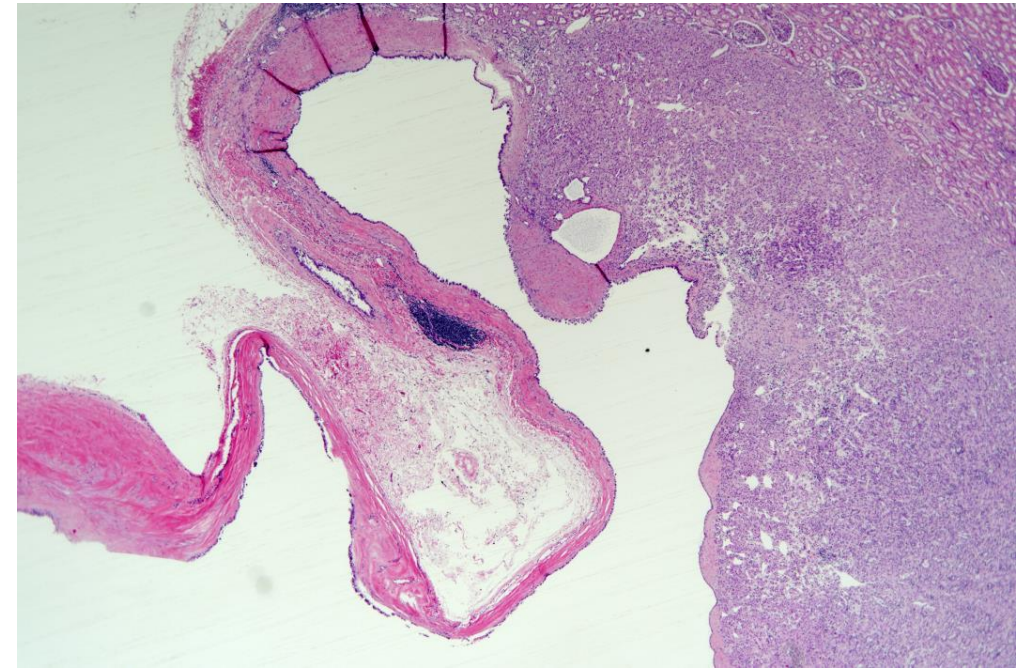

Figure 2. The tumor comprised a mixture of variably sized cysts and tubules (left side). The right side showed poorly differentiated tumors. (H\&E stain, $\times 20$ ). 


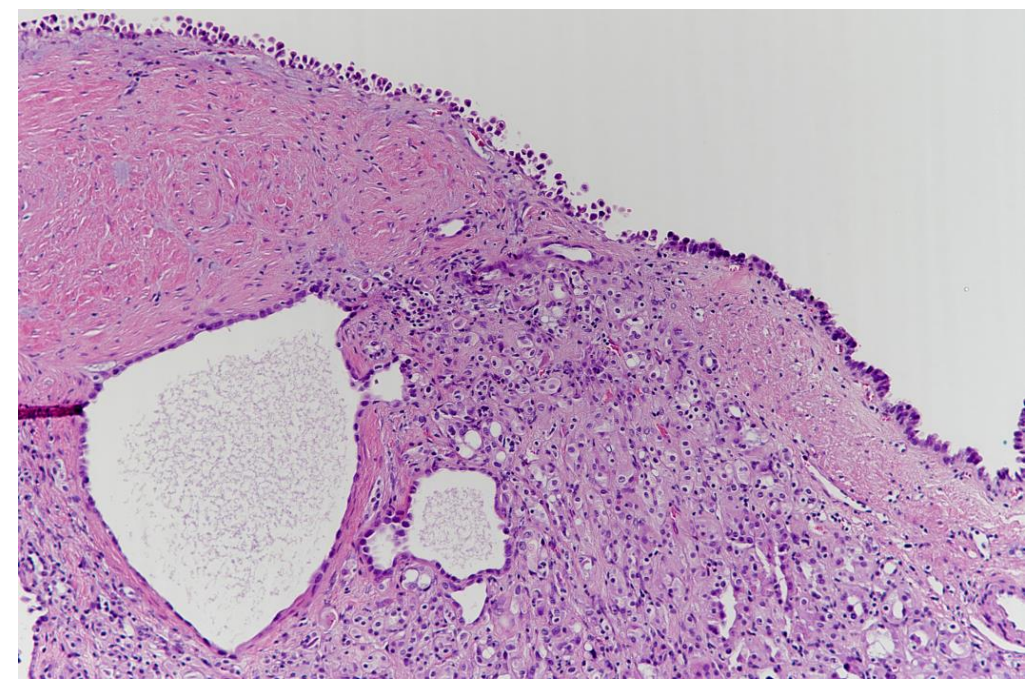

(a)

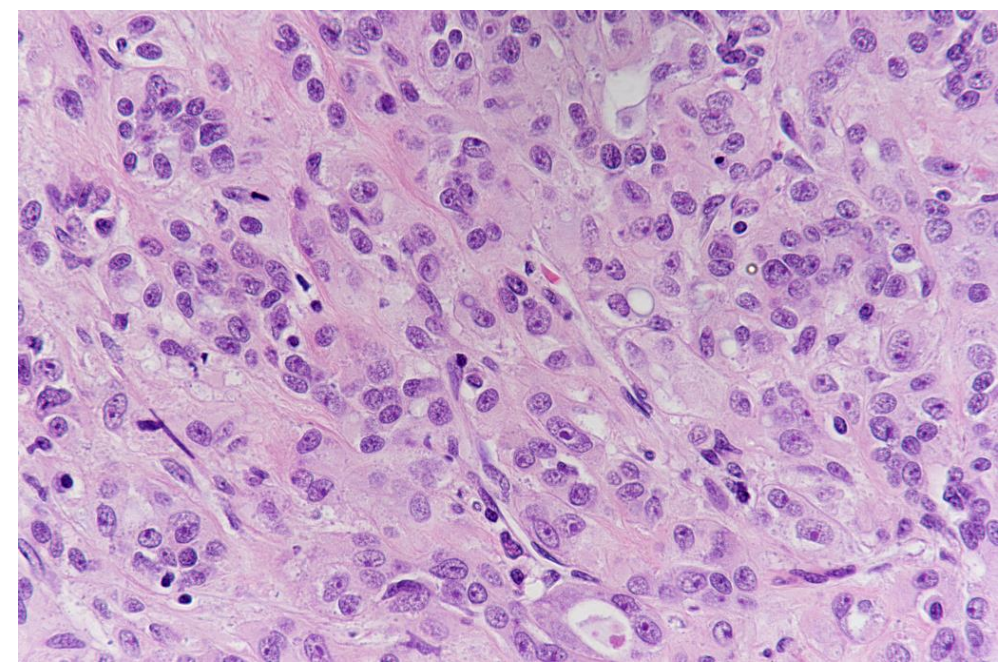

(b)

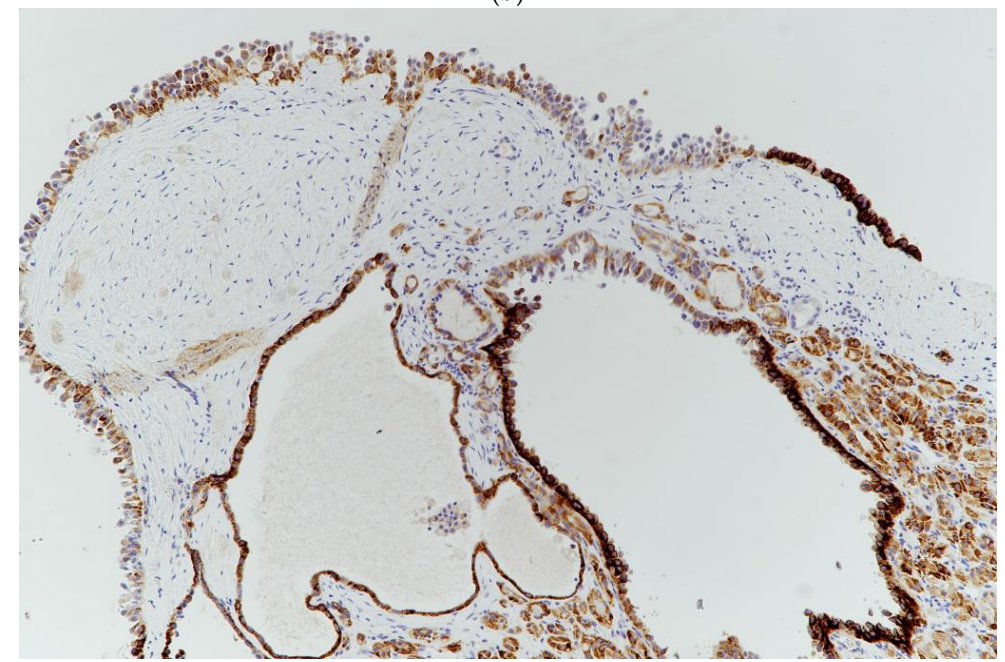

(c)

Figure 3. (a) The tubules and cysts were lined by a single layer of flattened, cuboidal or columnar cells. Hobnailing was present. The subepithelial area showed fibrous stroma and poorly differentiated tumor cells (H\&E stain, $\times 100)$. (b) The tumor contained poorly differentiated cells that had pleomorphic nuclei and prominent nucleoli $(H \& E$ stain, $\times 400)$. (c) The poorly differentiated area showed positivity for AMACR $(\times 200)$. 


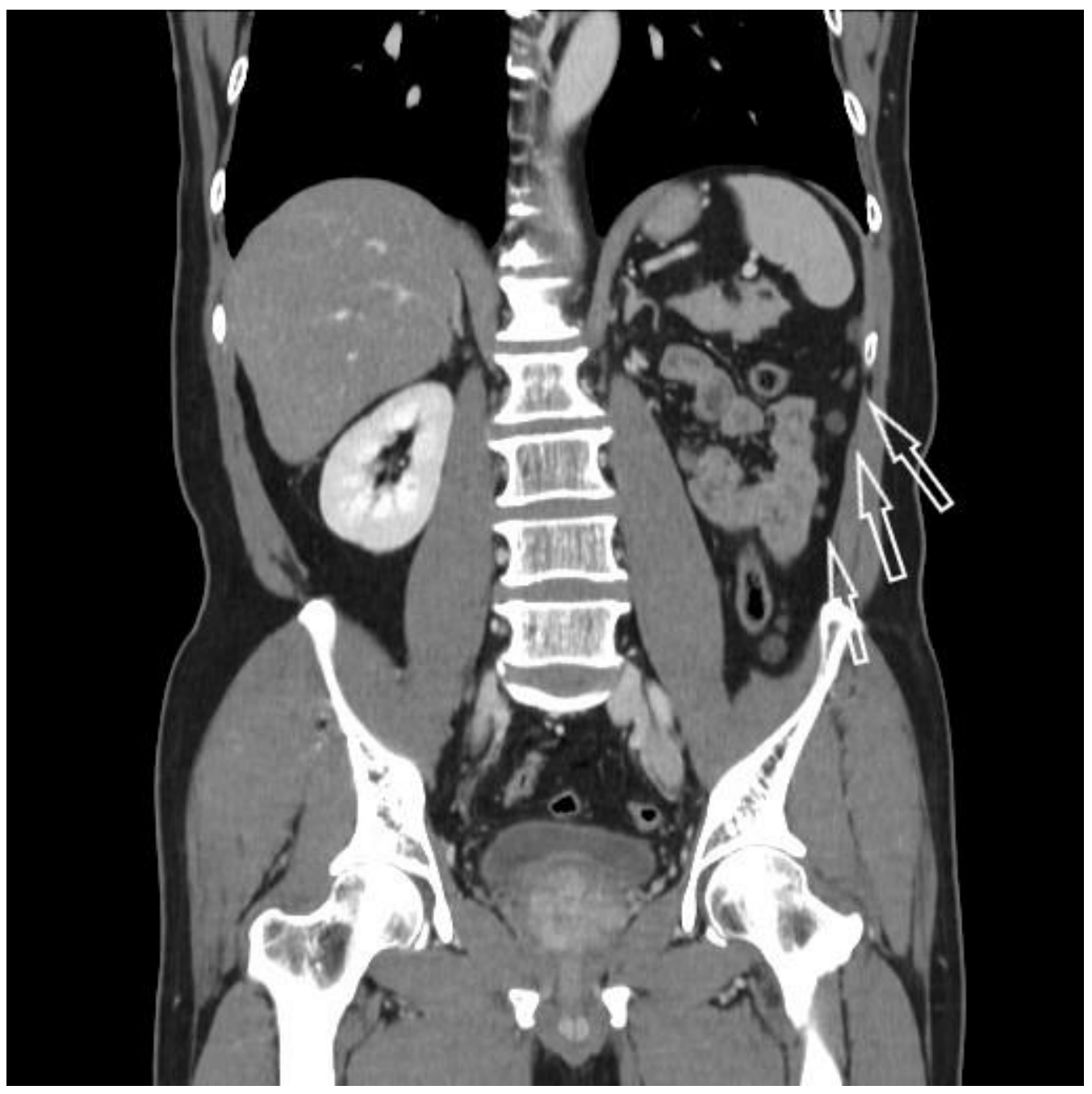

Figure 4. Eighteen months later, multiple small hypodense lesions in the left subphrenic space and along the lateral portion of the left retroperitoneal space (arrows) were noted on an abdominal CT scan.

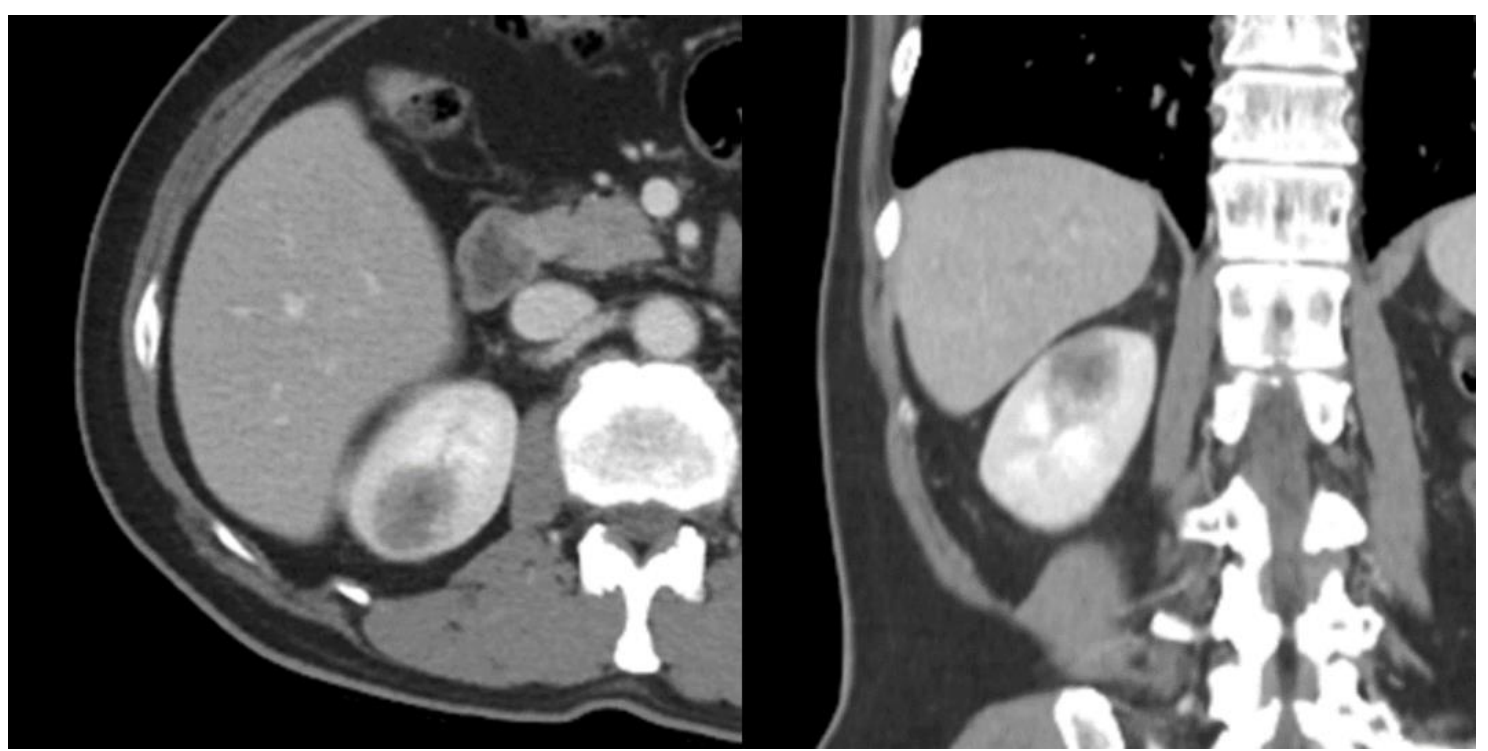

Figure 5. A hypodense lesion of $2.0 \mathrm{~cm}$ was observed in the upper pole of the right kidney. 


\section{Discussion}

Tubulocystic RCC is a rare subtype of RCC that was recently included in the 2016 WHO classification of kidney [1]. The majority of these tumors exhibit indolent behavior with low metastatic potential. Only a few cases of tumors with local recurrence and metastases to the lymph node, liver, bone, pleura, and peritoneum have been reported [3-5]. The pre-operative diagnosis of tubulocystic RCC is challenging. If there is a solid portion inside the renal mass, the possibility of RCC can be considered, but if it has only a cystic component, these tumors are difficult to distinguish from tubulocystic RCC or renal cysts. In Cornelis's study of 16 tubulocystic RCC studied by CT, two were considered solid, seven were cystic, and seven were indeterminate [6]. Among cystic lesions, one was classified as purely cystic (Bosniak I), one as Bosniak II, one as Bosniak IIF, and four as Bosniak IV. In our case, the preoperative diagnosis was Bosniak II renal cyst based on CT findings. Detecting contrast enhancement on $\mathrm{CT}$ is critical and remains a challenge due to the very low vascularity of tubulocystic RCC and the small number of solid tissue components [6]. Magnetic resonance imaging is very useful for demonstrating the microcystic nature of these tumors, owing to its superior contrast resolution [7,8]. In addition, the ultrasound (US) is useful in identifying the tubulocystic RCC [9]. The US pattern of tubulocystic RCC exhibits high echogenicity and posterior acoustic enhancement because of its multicystic characteristics separated by multiple thin septae [6].

Tubulocystic RCC is a dominantly cystic renal epithelial neoplasm. Macroscopically, it comprises multiple small-to-medium-sized cysts and has a spongy cut surface. The nuclei were enlarged according to WHO/International Society of Urological Pathology (ISUP) grade 3 nucleoli. The cytoplasm had abundant eosinophilic and oncocytomalike features. Tumors presented grossly as a complex cystic mass, characteristic in male patients (M:F ratio of 7:1) during their seventh decade [4]. These tumors demonstrated a consistent morphology of variably cystically dilated tubules, admixed with a background of fibrous stroma, and lined by markedly atypical cells with eosinophilic cytoplasm and highgrade nuclei with prominent nucleoli (ISUP nucleolar grade 3) [4]. Most reported tumors have been at a low stage, with only rare reports of clinical progression and aggressive behavior [10-12]. The coexistence of poorly differentiated foci indicates a worse prognosis than that of the common type of tubulocystic RCC [13,14]. Al-Hussain and Zhao reported several cases of tubulocystic RCC with poorly differentiated foci that had metastases and local recurrences in the abdomen, pelvic cavity and bones $[13,15]$. Tubulocystic RCC with poorly differentiated foci should be distinguished from the hereditary leiomyomatosis renal cell carcinoma syndrome (HLRCC). Most tubulocystic RCCs with poorly differentiated foci have a characteristic nucleus in the form of a large nucleus with prominent inclusion-like eosinophilic nucleoli reminiscent of nuclear features described in HLRCC [16]. For a proper differential diagnosis, a thorough investigation of family history and genetic testing should be considered.

Complete surgical excision is the principal treatment modality for RCC. However, tubulocystic RCC is often misdiagnosed as a renal cyst, and some tubulocystic RCC is treated with renal cyst marsupialization, as was in our case [2]. In this case, risk of local recurrence even after radical nephrectomy following renal cyst marsupialization could be pre-sent. To date, the treatment for metastatic tubulocystic RCC has not been established. Treatment must be individualized and, therefore requires a multidisciplinary approach. There have been several case reports on the administration of chemotherapeutic agents or targeted agents. A few case reports have suggested a partial response to sunitinib (a tyro-sine kinase inhibitor) and everolimus (a mammalian target of rapamycin (mTOR) inhibitor) [17-19]. In our case, the patient achieved a partial response after the initial administration of temsirolimus, including a decrease in size and disappearance of several nodules. However, in the subsequent response evaluation, the effect of treatment was not sustained, and recurrence was observed in the contralateral kidney. For locally recurrent or oligometastatic RCC, metastasectomy, stereotactic body radiation therapy, or ablative treatment should be considered according to the National Comprehensive Cancer Network 
guidelines [20]. RFA is an appropriate treatment option for small RCC with durable oncological outcomes of 94-96.1\% disease-free survival and low complication rates [21,22]. Integrated with a systemic treatment strategy, RFA is safe and effective for the treatment of metastatic disease from RCC with good overall survival and long systemic treatment-free survival [23]. Concomitant RFA of recurrent RCC and targeted agents for metastatic lesions is a feasible approach in this challenging scenario.

In conclusion, most tubulocystic RCC have features of indolent tumors and rarely recur. However, given that tubulocystic RCC with poorly differentiated foci has an aggressive clinical course, more detailed follow-up is required. In cases of local and distant metastases, a multimodal treatment strategy is required.

Author Contributions: Conceptualization, G.-E.M.; writing—original draft preparation, T.-S.C. and G.-E.M.; writing—review and editing, D.-G.L., K.-Y.W. and G.-E.M. All authors have read and agreed to the published version of the manuscript.

Funding: This research received no external funding.

Institutional Review Board Statement: The study was conducted according to the guidelines of the Declaration of Helsinki, and approved by the Institutional Review Board of Kyung Hee University Hospital at Gangdong (KHNMC 2021-05-003 and 10 May 2021).

Informed Consent Statement: Informed consent was obtained from the patient involved in the study. Written informed consent has been obtained from the patient to publish this paper.

Data Availability Statement: Data sharing not applicable.

Acknowledgments: We appreciated Sung-Goo Chang, Kyung Hee University College of Medicine, for his inspiring advice and support.

Conflicts of Interest: The authors declare no conflict of interest.

\section{References}

1. Moch, H.; Cubilla, A.L.; Humphrey, P.A.; Reuter, V.E.; Ulbright, T.M. The 2016 WHO Classification of Tumours of the Urinary System and Male Genital Organs-Part A: Renal, Penile, and Testicular Tumours. Eur. Urol. 2016, 70, 93-105. [CrossRef] [PubMed]

2. Banerjee, I.; Yadav, S.S.; Tomar, V.; Yadav, S.; Talreja, S. Tubulocystic Renal Cell Carcinoma: A Great Imitator. Rev. Urol. 2016, 18, 118-121. [CrossRef]

3. Amin, M.B.; MacLennan, G.T.; Gupta, R.; Grignon, D.; Paraf, F.; Vieillefond, A.; Paner, G.P.; Stovsky, M.; Young, A.N.; Srigley, J.R.; et al. Tubulocystic carcinoma of the kidney: Clinicopathologic analysis of 31 cases of a distinctive rare subtype of renal cell carcinoma. Am. J. Surg. Pathol. 2009, 33, 384-392. [CrossRef] [PubMed]

4. Yang, X.J.; Zhou, M.; Hes, O.; Shen, S.; Li, R.; Lopez, J.; Shah, R.B.; Yang, Y.; Chuang, S.T.; Lin, F.; et al. Tubulocystic carcinoma of the kidney: Clinicopathologic and molecular characterization. Am. J. Surg. Pathol. 2008, 32, 177-187. [CrossRef] [PubMed]

5. Bhullar, J.S.; Thamboo, T.; Esuvaranathan, K. Unique case of tubulocystic carcinoma of the kidney with sarcomatoid features: A new entity. Urology 2011, 78, 1071-1072. [CrossRef]

6. Cornelis, F.; Hélénon, O.; Correas, J.M.; Lemaitre, L.; André, M.; Meuwly, J.Y.; Sengel, C.; Derchi, L.; Yacoub, M.; Verkarre, V.; et al. Tubulocystic renal cell carcinoma: A new radiological entity. Eur. Radiol. 2016, 26, 1108-1115. [CrossRef] [PubMed]

7. MacLennan, G.T.; Cheng, L. Tubulocystic carcinoma of the kidney. J. Urol. 2011, 185, 2348-2349. [CrossRef] [PubMed]

8. Narayanasamy, S.; Krishna, S.; Prasad Shanbhogue, A.K.; Flood, T.A.; Sadoughi, N.; Sathiadoss, P.; Schieda, N. Contemporary update on imaging of cystic renal masses with histopathological correlation and emphasis on patient management. Clin. Radiol. 2019, 74, 83-94. [CrossRef] [PubMed]

9. Oderda, M.; Maletta, F.; Palazzetti, A.; Faletti, R.; Falcone, M.; Marra, G.; Galliano, D.; Davico Bonino, L.; Gontero, P. Tubulocystic renal cell carcinoma disguised as a renal cyst. Minerva Urol. E Nefrol. Ital. J. Urol. Nephrol. 2016, 68, 451-455.

10. Tran, T.; Jones, C.L.; Williamson, S.R.; Eble, J.N.; Grignon, D.J.; Zhang, S.; Wang, M.; Baldridge, L.A.; Wang, L.; Montironi, R.; et al. Tubulocystic renal cell carcinoma is an entity that is immunohistochemically and genetically distinct from papillary renal cell carcinoma. Histopathology 2016, 68, 850-857. [CrossRef] [PubMed]

11. Osunkoya, A.O.; Young, A.N.; Wang, W.; Netto, G.J.; Epstein, J.I. Comparison of gene expression profiles in tubulocystic carcinoma and collecting duct carcinoma of the kidney. Am. J. Surg. Pathol. 2009, 33, 1103-1106. [CrossRef] [PubMed]

12. Zhou, M.; Yang, X.J.; Lopez, J.I.; Shah, R.B.; Hes, O.; Shen, S.S.; Li, R.; Yang, Y.; Lin, F.; Elson, P.; et al. Renal tubulocystic carcinoma is closely related to papillary renal cell carcinoma: Implications for pathologic classification. Am. J. Surg. Pathol. 2009, 33, 1840-1849. [CrossRef] [PubMed]

13. Al-Hussain, T.O.; Cheng, L.; Zhang, S.; Epstein, J.I. Tubulocystic carcinoma of the kidney with poorly differentiated foci: A series of 3 cases with fluorescence in situ hybridization analysis. Hum. Pathol. 2013, 44, 1406-1411. [CrossRef] [PubMed] 
14. Smith, S.C.; Trpkov, K.; Chen, Y.B.; Mehra, R.; Sirohi, D.; Ohe, C.; Cani, A.K.; Hovelson, D.H.; Omata, K.; McHugh, J.B.; et al. Tubulocystic Carcinoma of the Kidney with Poorly Differentiated Foci: A Frequent Morphologic Pattern of Fumarate Hydratase-deficient Renal Cell Carcinoma. Am. J. Surg. Pathol. 2016, 40, 1457-1472. [CrossRef]

15. Zhao, M.; Teng, X.; Ru, G.; Zhao, Z.; Hu, Q.; Han, L.; He, X. Tubulocystic renal cell carcinoma with poorly differentiated foci is indicative of aggressive behavior: Clinicopathologic study of two cases and review of the literature. Int. J. Clin. Exp. Pathol. 2015, 8, 11124-11131.

16. Al-Hussain, T.O.; Alahmadi, B.; Junejo, N.N.; Alshammari, K.; Bakshi, N.; Alzahrani, H.M. Tubulocystic renal cell carcinoma with poorly differentiated foci and loss of fumarate hydratase: A case report. Urol. Case Rep. 2020, 33, 101236. [CrossRef]

17. Mego, M.; Sycova-Mila, Z.; Rejlekova, K.; Rychly, B.; Obertova, J.; Rajec, J.; Hes, O.; Mardiak, J. Sunitinib in the treatment of tubulocystic carcinoma of the kidney. A case report. Ann. Oncol. Off. J. Eur. Soc. Med. Oncol. 2008, 19, 1655-1656. [CrossRef]

18. Teramoto, S.; Niwakawa, M.; Muraoka, K.; Ogawa, M.; Kunieda, F.; Matsuzaki, M.; Yamashita, R.; Matsui, T.; Yamaguchi, R.; Tobisu, K. Tubulocystic carcinoma of the kidney. Nihon Hinyokika Gakkai Zasshi Jpn. J. Urol. 2011, 102, 696-700. [CrossRef]

19. Urabe, F.; Miki, J.; Yanagisawa, T.; Kimura, T.; Nakano, M.; Suzuki, M.; Kishimoto, K.; Egawa, S. A Case of Metastatic Tubulocystic Carcinoma of the Kidney Treated with Molecularly Targeted Therapy. Hinyokika Kiyo Acta Urol. Jpn. 2016, 62, 569-574. [CrossRef]

20. Motzer, R.J.; Jonasch, E.; Michaelson, M.D.; Nandagopal, L.; Gore, J.L.; George, S.; Alva, A.; Haas, N.; Harrison, M.R.; Plimack, E.R.; et al. NCCN Guidelines Insights: Kidney Cancer, Version 2. 2020. J. Natl. Compr. Cancer Netw. JNCCN 2019, 17, $1278-1285$. [CrossRef] [PubMed]

21. Curry, D.; Pahuja, A.; Loan, W.; Thwaini, A. Radiofrequency Ablation of Small Renal Masses: Outcomes, Complications and Effects on Renal Function. Curr. Urol. 2017, 11, 196-200. [CrossRef] [PubMed]

22. Kim, H.J.; Park, B.K.; Park, J.J.; Kim, C.K. CT-Guided Radiofrequency Ablation of T1a Renal Cell Carcinoma in Korea: Mid-Term Outcomes. Korean J. Radiol. 2016, 17, 763-770. [CrossRef] [PubMed]

23. Gonnet, A.; Salabert, L.; Roubaud, G.; Catena, V.; Brouste, V.; Buy, X.; Gross Goupil, M.; Ravaud, A.; Palussière, J. Renal cell carcinoma lung metastases treated by radiofrequency ablation integrated with systemic treatments: Over 10 years of experience. BMC Cancer 2019, 19, 1182. [CrossRef] [PubMed] 